\title{
Sensitivity of mononuclear leucocytes to glucocorticoids in elderly hip-fracture patients resistant to suppression of plasma cortisol by dexamethasone
}

\author{
E A M van Rijen, R A Harvey, R N Barton, J G Rose and M A Horan ${ }^{1}$ \\ North Western Injury Research Centre, Hope Hospital, Salford, UK and ${ }^{1}$ University Department of Geriatric Medicine, Withington Hospital, \\ Manchester, UK \\ (Correspondence should be addressed to R N Barton, North Western Injury Research Centre, Stopford Building, University of Manchester, \\ Oxford Road, Manchester M13 9PT, UK) \\ (R A Harvey is now at Department of Orthopaedic Surgery, Arrowe Park Hospital, Upton, Wirral, Cheshire, UK) \\ (M A Horan is now at Department of Geriatric Medicine, Hope Hospital, Salford, UK)
}

\begin{abstract}
Objective: Elderly women with proximal femur fracture show a prolonged increase in plasma cortisol, which could have undesirable catabolic effects. Suppression of cortisol by dexamethasone is impaired, suggesting resistance to glucocorticoid effects at feedback inhibitory sites. We therefore wished to find out whether peripheral glucocorticoid sensitivity is normal.

Design: Peripheral blood mononuclear leucocytes were used as a model tissue. Blood samples were taken from elderly women about 2 weeks after hip fracture and from elderly control women. Each patient was then given $1 \mathrm{mg}$ dexamethasone at $2300 \mathrm{~h}$ followed by further sampling at 0800 and $1600 \mathrm{~h}$ the next day.

Methods: Glucocorticoid-receptor binding parameters were measured by incubating whole cells with $\left[{ }^{3} \mathrm{H}\right]$ dexamethasone for $2 \mathrm{~h}$ at $37^{\circ} \mathrm{C}$. Inhibition of cell proliferation by dexamethasone was assessed by addition of $\left[{ }^{3} \mathrm{H}\right]$ thymidine to cells cultured for $65 \mathrm{~h}$ with concanavalin A. Cortisol and dexamethasone concentrations were measured in the dexamethasone suppression test.

Results: As expected, the hip-fracture patients had raised morning cortisol concentrations and impaired suppression by dexamethasone. The cells of the patients had similar numbers of glucocorticoid receptors to those of the control subjects but higher values for $K_{d}$ (i.e. a lower binding affinity). The cells of the patients incorporated less $\left[{ }^{3} \mathrm{H}\right]$ thymidine than the control cells in the absence of dexamethasone. The percentage inhibition by a saturating concentration of dexamethasone was unchanged but the concentration giving half-maximal inhibition was decreased (sensitivity was increased) at the higher of the two concanavalin A concentrations used.

Conclusions: These experiments in mononuclear leucocytes give no evidence of peripheral resistance to glucocorticoids in hip-fracture patients with impaired suppression of cortisol by dexamethasone.
\end{abstract}

European Journal of Endocrinology 138 659-666

\section{Introduction}

Elderly women with proximal femur fracture show a prolonged adrenocortical response to injury. By 2-3 weeks plasma cortisol is higher than in younger patients with injuries of similar or greater severity (1). It is also higher than in healthy elderly control subjects or geriatric patients receiving long-term care, and these differences continue for at least 8 weeks (2). The increase in cortisol is substantial. At about 2 weeks after injury, urinary free cortisol excretion is about three times higher than in healthy subjects (3), and indirect estimates suggest a similar increase in the plasma free cortisol concentration averaged over $24 \mathrm{~h}$ (R N Barton, J G Rose \& M A Horan, unpublished observations).
Proximal femur fracture in old people is known to carry not only a substantial mortality (4) but also a high morbidity. Recovery is often slow and many patients fail to regain their previous level of independence (5). It is possible that cortisol contributes to this deterioration through its catabolic effects. Not only may it retard wound healing and fracture repair (6) but it would also be expected to increase net protein breakdown in uninjured muscle (7) and thereby hinder mobilisation in patients who already have poor muscle function. However, it is conceivable that such effects are less than expected because of glucocorticoid resistance. Hip-fracture patients usually show incomplete suppression of plasma cortisol by dexamethasone $(2,8)$. There is evidence (9) that the receptors responsible for this action are the same as the Type II or glucocorticoid 
receptors (GRs) mediating peripheral glucocorticoid effects, including catabolic changes in muscle (10). Down-regulation of GRs by raised glucocorticoid concentrations is well established in vitro and is sometimes seen in man (11).

Because of the potential for inhibiting cortisol secretion therapeutically, it is important to establish whether elderly hip-fracture patients are resistant to glucocorticoids or whether they would be expected to suffer the usual deleterious consequences of persistently high cortisol concentrations. We therefore looked for biochemical evidence of glucocorticoid resistance in peripheral blood mononuclear leucocytes (PBMLs). This tissue would be involved in any immunosuppressive effects of cortisol, and its glucocorticoid sensitivity may reflect that of other tissues such as muscle. We measured the whole-cell binding characteristics of dexamethasone and a well-known glucocorticoid effect, inhibition of concanavalin A (ConA)-induced mitogenesis by dexamethasone $(12,13)$. We carried out overnight dexamethasone suppression tests in the same patients and included measurement of plasma dexamethasone, which many studies have shown to be a determinant, although not the only one, of the response to this test in non-suppressors (14).

\section{Subjects and methods Subjects and procedure}

Studies were carried out in eight control women aged 63-85 years (median 74 years) and 15 injured women aged 67-93 years (median 81 years). The difference in ages was not statistically significant. The control women (Table 1) were not selected to be 'disease-free' but had only minor health problems and perceived their health to be good. The injured women had all sustained proximal femur fracture (eight extracapsular, seven intracapsular) which had been treated surgically (by internal fixation or hemiarthroplasty) within $72 \mathrm{~h}$. One patient had in addition a Colles' fracture of the wrist. No patient had concomitant disease likely to affect adrenal function or was receiving drugs likely to do so. Studies were started 10-19 (median 14) days after injury.

On the first day of the study, a blood sample (40$80 \mathrm{ml}$ ) was taken from each subject at $1000-1130 \mathrm{~h}$ with heparin as anticoagulant for separation of PBMLs, differential cell counting and measurement of plasma cortisol. At $2300 \mathrm{~h}$ on the same day the patients, but not the control subjects, received $1 \mathrm{mg}$ dexamethasone (Organon, Cambridge, UK) orally. On the following day, at 0800 and $1600 \mathrm{~h}$, further blood samples were taken from the patients for measurement of plasma cortisol and dexamethasone.

The studies were approved by the ethics committees of Salford and Stockport Health Authorities and all subjects gave their informed consent to the procedure.

\section{Preparation of mononuclear leucocytes}

Blood was diluted 1:1 with PBS (Flow Laboratories, Rickmansworth, Herts, UK; pH 7.4), layered on to Ficoll 400 solution (Lymphocyte Separation Medium; Flow Laboratories; medium/diluted blood, 1:2, v/v) and centrifuged at $1000 \mathrm{~g}$ for $45 \mathrm{~min}$ at $4{ }^{\circ} \mathrm{C}$. The mononuclear-cell layer was taken and the cells were washed three times in PBS and resuspended in complete RPMI 1640 medium (Flow Laboratories), containing 10\% (v/v) foetal calf serum (Globe Farm, Esher, Surrey, UK), $2 \mathrm{mmol} / \mathrm{l}$ glutamine (Flow Laboratories) and $5000 \mathrm{U} / \mathrm{ml}$ gentamicin (Sigma, Poole, Dorset, UK). In each preparation the ratio of monocytes to lymphocytes was measured by staining the former for non-specific esterase (15). Viability measured by exclusion of trypan blue (Flow Laboratories) was always greater than $95 \%$.

\section{Measurement of dexamethasone binding}

Tubes each containing about $8 \times 10^{6}$ PBMLs suspended in complete RPMI 1640 medium were incubated with $1 \mathrm{nmol} / \mathrm{l}(37 \mathrm{nCi} / \mathrm{ml})\left[1,2,4-{ }^{3} \mathrm{H}\right]$ dexamethasone (Amersham International, Amersham, Bucks, UK) with or without 14 or $2000 \mathrm{nmol} / \mathrm{l}$ unlabelled dexamethasone (Sigma) in a total volume of $1 \mathrm{ml}$ for $2 \mathrm{~h}$ in a shaking waterbath at $37^{\circ} \mathrm{C}$. Except for single label-alone tubes in one patient and one control subject, all incubations were performed at least in duplicate; usually there were enough cells for more than six tubes, and more replicates were then included at $15 \mathrm{nmol} / \mathrm{l}$ than at the other two dexamethasone concentrations. At the end of the incubation, $2 \mathrm{ml}$ ice-cold PBS was added and the

Table 1 Details of control subjects.

\begin{tabular}{lcll}
\hline Subject & Age (years) & \multicolumn{1}{c}{ Medical conditions } & Medications \\
\hline 1 & 76 & Hypertension, Ménière's disease & Aspirin, cinnarazine \\
2 & 71 & Mild osteoarthritis, mild hypertension & None \\
3 & 63 & Mild osteoarthritis & None \\
4 & 83 & Cystocoele, osteoarthritis & Paracetamol \\
5 & 85 & Hypertension, glaucoma, basal cell carcinoma & Atenolol, pilocarpine, bendrofluazide \\
6 & 81 & Osteoarthritis & Paracetamol \\
7 & 68 & Psoriasis, mild osteoarthritis, mild obesity & None \\
8 & 69 & Mild hypertension & Amiloride, cyclopenthiazide \\
\hline
\end{tabular}


suspension was centrifuged at $700 \mathrm{~g}$; the cells were then washed twice in PBS. Scintillation counting in Optiphase Hisafe II (LKB Scintillation Products, Loughborough, Leics, UK) was performed with a TriCarb 1500 liquid scintillation analyser (Packard, Pangbourne, Berks, UK) on the cells and supernatants apart from the last wash. The count rates were stable for at least $48 \mathrm{~h}$. Internal standardisation with $\left[{ }^{3} \mathrm{H}\right]$ toluene (Packard) was used.

Values for the 'concentration' and dissociation constant $\left(K_{\mathrm{d}}\right)$ of high-affinity binding sites were calculated by the Woolf plot (16) from the bound/free ratios at dexamethasone concentrations of 1 and $15 \mathrm{nmol} / \mathrm{l}$, corrected for non-specific binding by subtracting the mean bound/free ratio at $2000 \mathrm{nmol} / \mathrm{l}$ dexamethasone. The Woolf plot has theoretical advantages over the Scatchard plot (16), although the choice made little difference in the present studies because the bound/free ratios were very reproducible. Computer runs with large numbers of simulated data showed that the estimates of the binding parameters were unbiased and that the choice of concentrations was close to optimal.

Preliminary experiments established that the incubation time was adequate to achieve equilibrium, that the non-specific binding was non-saturable and that the binding parameters were unlikely to be affected by cortisol originally present in the blood.

\section{Mitogenesis-inhibition assay}

PBMLs $\left(2 \times 10^{5} /\right.$ well $)$ suspended in complete RPMI 1640 medium $(0.25 \mathrm{ml})$ were cultured in quadruplicate in flat-bottomed microtitre plates (Bibby; Philip Harris, Manchester, UK) in the presence of ConA (Sigma; 1 and $10 \mu \mathrm{g} / \mathrm{ml})$ and dexamethasone $(0,0.1,1,3,10$ and $100 \mathrm{nmol} / \mathrm{l}$ ) at $37^{\circ} \mathrm{C}$ in an atmosphere of $5 \% \mathrm{CO}_{2}$ for $65 \mathrm{~h}$. [methyl- $\left.{ }^{3} \mathrm{H}\right]$ Thymidine (Amersham International; $0.5 \mu \mathrm{Ci} /$ well) was then added to the cultures, and $5 \mathrm{~h}$ later the cells were transferred to filter paper with a cell harvester (Titertek; Flow Laboratories). The filters were placed in scintillation vials and soaked with $0.5 \mathrm{ml}$ ethanol for $30 \mathrm{~min}$ before addition of Hisafe II and scintillation counting. The count rates were stable for at least $48 \mathrm{~h}$. Cells from most subjects were incubated similarly with 3 and $30 \mu \mathrm{g} / \mathrm{ml}$ ConA in the absence of dexamethasone to establish dose-response curves for the mitogen.

\section{Measurement of plasma corticosteroid concentrations}

Cortisol was determined with an RIA kit (Immunodiagnostics Ltd, Boldon, Tyne and Wear, UK). Dexamethasone was measured by RIA with an antiserum kindly supplied by Professor P Vecsei (University of Heidelberg, Germany). Because this gave up to $0.4 \%$ cross-reactivity with cortisol, $80-90 \%$ of the cortisol was first removed by incubating $0.5 \mathrm{ml}$ plasma with $0.5 \mathrm{ml}$ cortisol-free serum (Biogenesis, Bournemouth, Dorset, UK), to increase the amount bound to corticosteroid-binding globulin, and passing it rapidly through a Sep-Pak $\mathrm{C}_{18}$ cartridge (Waters, Watford, Herts, UK) which adsorbed dexamethasone but not bound cortisol. The dexamethasone was eluted with methanol which was then evaporated to dryness in the assay tubes. Recovery was 94-98\%. The RIA was performed overnight at room temperature with $\left[1,2,4,6,7-{ }^{3} \mathrm{H}\right]$ dexamethasone (Amersham) in $0.08 \mathrm{~mol} / \mathrm{l}$ borate buffer, $\mathrm{pH}$ 8.0, and separation was with dextran-coated charcoal. A small correction $(<10 \%)$ was made for the immunoreactivity due to residual cortisol, the quantity of which was measured by extraction of samples with added $\left[{ }^{3} \mathrm{H}\right]$ cortisol run with each assay.

\section{Statistical analysis}

With the exception of the data for $\left[{ }^{3} \mathrm{H}\right]$ thymidine incorporation in the absence of dexamethasone, for which a two-way analysis of variance was carried out on the logarithms (see Fig. 2), non-parametric statistics were used throughout. Differences between paired data were assessed with Wilcoxon's signed-rank test and differences between unpaired data with Wilcoxon's twosample rank test (17). Correlations were tested by Kendall's rank correlation method (18).

\section{Results}

As expected $(2,8)$, the morning plasma cortisol concentration (in the blood sample from which cells were prepared) was higher in the injured patients than in the control subjects (Table 2). On the morning after administration of dexamethasone, the patients had a wide range of cortisol concentrations (Fig. 1). Although the control subjects were not given dexamethasone, the concentrations in the patients were all above the highest of the post-dexamethasone cortisol concentrations measured earlier by the same method in control subjects (2). Moreover, 12 of 14 patients were non-suppressors by the usual criterion of $0.138 \mu \mathrm{mol} / \mathrm{l}$ (19). By the afternoon there was no consistent further change and 9 of 12 patients were non-suppressors. The plasma dexamethasone concentration also varied widely in the morning but, in contrast with the lack of change in cortisol, it had fallen by at least half in every patient in the afternoon (Fig. 1). The afternoon values correlated with the morning ones for both cortisol $(P<0.01)$ and dexamethasone $(P<0.001)$. At neither time was there a significant correlation between the cortisol and dexamethasone concentrations.

The differential cell count showed a marked fall in the number of lymphocytes and rise in the number of granulocytes in the injured patients (Table 2). The percentage of monocytes in the PBML preparation was considerably higher in the injured patients than in the 
Table 2 Plasma cortisol concentration, blood cell counts, parameters for dexamethasone binding and parameters for inhibition of mitogenesis by dexamethasone in mononuclear leucocytes from elderly control women and women with proximal femur fracture. Results are given as median with range in parentheses.

\begin{tabular}{|c|c|c|}
\hline & Control women & Injured women \\
\hline Plasma cortisol $(\mu \mathrm{mol} / \mathrm{l})$ & $0.34(0.19-0.60)$ & $0.55(0.40-1.24)^{b}$ \\
\hline $\begin{array}{l}10^{-9} \times \text { cell count in blood }(\text { cells } / \text { l) } \\
\text { Lymphocytes } \\
\text { Monocytes } \\
\text { Granulocytes }\end{array}$ & $\begin{array}{l}2.6(1.6-3.6) \\
0.6(0.6-0.7) \\
4.7(3.0-5.7)\end{array}$ & $\begin{array}{l}1.3(0.8-2.3)^{\mathrm{a}} \\
0.7(0.2-1.6) \\
8.1(4.9-17.6)^{\mathrm{b}}\end{array}$ \\
\hline $\begin{array}{l}\text { Monocyte content of cell preparation }(\%) \dagger \\
{\left[{ }^{3} \mathrm{H}\right] \text { Dexamethasone binding }}\end{array}$ & $16(13-33)$ & $31(22-43)^{c}$ \\
\hline $\begin{array}{l}\text { Receptor content (no./cell) } \\
K_{\mathrm{d}}(\mathrm{nmol} / \mathrm{l})\end{array}$ & $\begin{array}{c}6200(5300-7400) \\
\quad 7.7(7.0-8.3)\end{array}$ & $\begin{array}{r}7100(5000-8700) \\
9.8(7.3-15.5)^{c}\end{array}$ \\
\hline $\begin{array}{l}{\left[{ }^{3} \mathrm{H}\right] \text { Thymidine incorporation with } 1 \mu \mathrm{g} / \mathrm{ml} \text { ConA }} \\
\text { Maximal inhibition (\%) } \\
\text { IC }_{50}(\mathrm{nmol} / \mathrm{l})\end{array}$ & $\begin{array}{l}95(90-99) \\
2.0(0.4-4.0)\end{array}$ & $\begin{array}{l}92(78-99) \\
1.5(0.1-4.4)\end{array}$ \\
\hline $\begin{array}{l}{\left[{ }^{3} \mathrm{H}\right] \text { Thymidine incorporation with } 10 \mu \mathrm{g} / \mathrm{ml} \text { ConA }} \\
\text { Maximal inhibition }(\%) \\
I_{50}(\mathrm{nmol} / \mathrm{l})\end{array}$ & $\begin{array}{l}60(43-91) \\
7.7(4.9-8.8) \|\end{array}$ & $\begin{array}{l}69(32-87) \\
3.8(0.1-17.9)^{\mathrm{a}}\end{array}$ \\
\hline
\end{tabular}

$n=8$ for control women, $n=15$ for injured women, except as follows: ${ }^{*} n=4$ for controls, $n=14$ for injured; $\nmid n=14$ for injured; $\ddagger n=12$ for injured; $\|$ could not be calculated for one subject. Differences from control women were significant at ${ }^{\mathrm{a}} P<0.02,{ }^{\mathrm{b}} P<0.01,{ }^{\mathrm{c}} P<0.001$ (Wilcoxon's twosample rank test).

control subjects (Table 2). It did not differ from the percentage expected from the two cell counts in whole blood (Wilcoxon's signed-rank test).

Measurement of $\left[{ }^{3} \mathrm{H}\right]$ dexamethasone binding showed no difference in the number of GRs between PBMLs from injured patients and those from control subjects (Table $2)$. However, $K_{d}$ was higher in the patients (Table 2), indicating a lower affinity. The two binding parameters did not correlate with each other in either group.

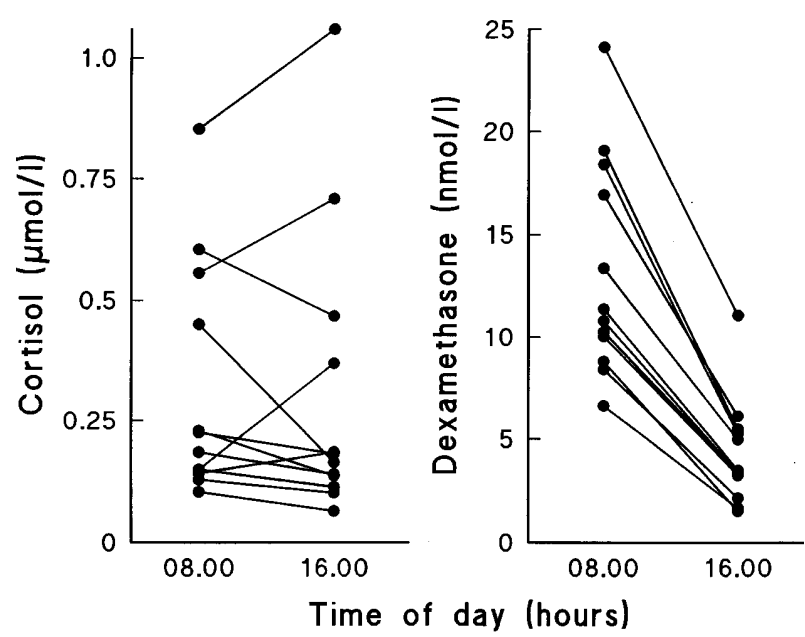

Figure 1 Plasma cortisol and dexamethasone concentrations at 0800 and $1600 \mathrm{~h}$ in elderly women with proximal femur fracture who had taken $1 \mathrm{mg}$ dexamethasone at $2300 \mathrm{~h}$ on the previous day. The difference in concentration between the two times was not significant for cortisol but was significant at $P<0.01$ for dexamethasone (Wilcoxon's signed-rank test). Note that two points at $0800 \mathrm{~h}$ (cortisol 0.14 and $0.15 \mu \mathrm{mol} / \mathrm{l}$, dexamethasone 8.6 and $8.6 \mathrm{nmol} / \mathrm{l})$ did not have accompanying $1600 \mathrm{~h}$ values.
In the absence of dexamethasone, ConA caused a dose-dependent increase in $\left[{ }^{3} \mathrm{H}\right]$ thymidine incorporation into cultured PBMLs (Fig. 2). At $1 \mu \mathrm{g} / \mathrm{ml}$ ConA, incorporation was a median of $20 \times$ that in the absence of ConA (results not shown); peak stimulation was observed at $10 \mu \mathrm{g} / \mathrm{ml}$. At all ConA concentrations, $\left[{ }^{3} \mathrm{H}\right]$ thymidine incorporation in the PBMLs



Figure 2 Relationship between $\left[{ }^{3} \mathrm{H}\right]$ thymidine $\left(\left[{ }^{3} \mathrm{H}\right] \mathrm{TdR}\right)$ incorporation and ConA concentration in mononuclear leucocytes from control elderly women $(O)$ and women after proximal femur fracture (๑). Data are for $2 \times 10^{5}$ cells incubated with $0.5 \mu \mathrm{Ci}\left[{ }^{3} \mathrm{H}\right]$ thymidine. Values are shown as geometric means with S.E.M. ranges; note that both axes are logarithmic. Only subjects with data at all four ConA concentrations are shown; $n=5$ for control subjects, 11 for injured patients. The difference between the two groups was significant by two-way analysis of variance performed on the logarithms $(P<0.025)$ 


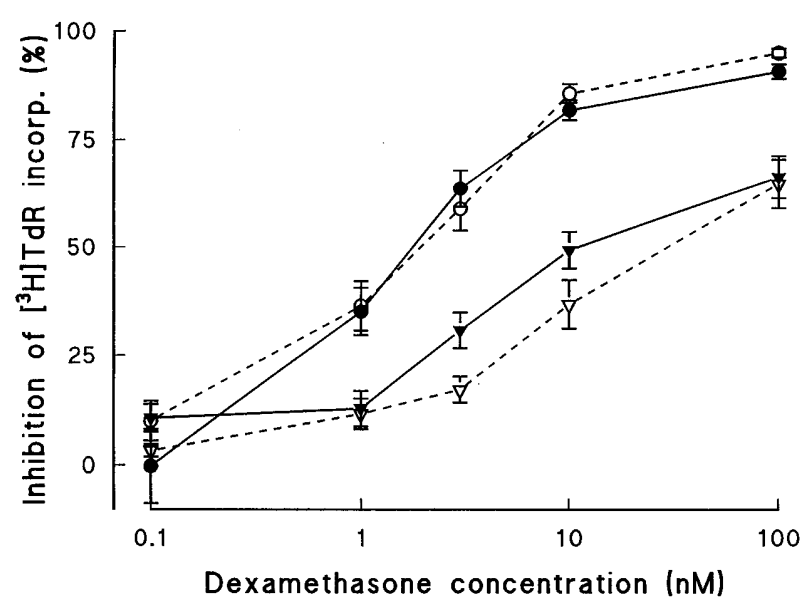

Figure 3 Relationship between inhibition of $\left[{ }^{3} \mathrm{H}\right]$ thymidine $\left(\left[{ }^{3} \mathrm{H}\right] \mathrm{TdR}\right)$ incorporation and dexamethasone concentration in mononuclear leucocytes from control elderly women and women after proximal femur fracture. $(\bigcirc)$ and $(\bullet)$, control and injured women respectively with $1 \mu \mathrm{g} / \mathrm{ml}$ ConA; $(\nabla)$ and $(\boldsymbol{\nabla})$, control and injured women respectively with $10 \mu \mathrm{g} / \mathrm{ml}$ ConA. Values are shown as mean \pm S.E.M.; $n=8$ for control subjects, 12 for injured patients. Statistical analysis of parameters calculated from the data is given in Table 2.

from hip-fracture patients was around half that in those from control subjects, leading to parallel concentration-response curves when the data were plotted as logarithms (Fig. 2).

ConA concentrations of 1 and $10 \mu \mathrm{g} / \mathrm{ml}$ were chosen for studying the inhibitory effects of dexamethasone. At $100 \mathrm{nmol} / \mathrm{l}$ dexamethasone, GRs should have been close to saturation. Consequently we took inhibition at $100 \mathrm{nmol} / \mathrm{l}$ to be maximal and calculated the dexamethasone concentration giving half-maximal inhibition $\left(\mathrm{IC}_{50}\right)$ accordingly, using log-linear plots (Fig. 3) to interpolate between concentrations. With $1 \mu \mathrm{g} / \mathrm{ml}$ ConA, the dose-response curves for the injured patients and control subjects were very similar (Fig. 3) and there was no difference in maximal percentage inhibition (which approached $100 \%$ ) or $\mathrm{IC}_{50}$ between them (Table $2)$. With $10 \mu \mathrm{g} / \mathrm{ml}$ ConA, maximal inhibition was less nearly complete and $\mathrm{IC}_{50}$ was higher. The curve was shifted to the left for the patients (Fig. 3) and the $\mathrm{IC}_{50}$ was lower than that for the controls; there was again no difference in maximal percentage inhibition (Table 2). For the patients, maximal inhibition correlated positively with baseline $\left[{ }^{3} \mathrm{H}\right]$ thymidine incorporation (in the absence of dexamethasone) when the ConA concentration was $1 \mu \mathrm{g} / \mathrm{ml}(P<0.05)$ but not when it was $10 \mu \mathrm{g} /$ $\mathrm{ml}$. At neither ConA concentration did $\mathrm{IC}_{50}$ correlate with baseline $\left[{ }^{3} \mathrm{H}\right]$ thymidine incorporation or maximal inhibition. The values for maximal inhibition and $\mathrm{IC}_{50}$ at $10 \mu \mathrm{g} / \mathrm{ml}$ ConA did not correlate with those at $1 \mu \mathrm{g} / \mathrm{ml}$.

At neither ConA concentration did the parameters for inhibition of mitogenesis by dexamethasone correlate with the parameters for GR binding, i.e. there was no correlation between maximal percentage inhibition and the number of receptors per cell or between $\mathrm{IC}_{50}$ and $K_{\mathrm{d}}$. In absolute terms, at $1 \mu \mathrm{g} / \mathrm{ml}$ ConA, $\mathrm{IC}_{50}$ was much lower than $K_{\mathrm{d}}$; at $10 \mu \mathrm{g} / \mathrm{ml}$ the difference was narrowed for the injured patients and had disappeared for the control subjects (Table 2). At both ConA concentrations, $\mathrm{IC}_{50}$ was much more variable than $K_{\mathrm{d}}$.

\section{Discussion}

This study was based on our previous observation of a raised cortisol concentration and impaired suppression by dexamethasone in elderly women with proximal femur fracture $(2,8)$. Both these findings have been confirmed (Table 2, Fig. 1). Most patients had postdexamethasone cortisol concentrations above the criterion value of $0.138 \mu \mathrm{mol} / \mathrm{l}(19)$. In contrast, healthy (screened) elderly women and geriatric patients receiving continuing care for chronic medical conditions all had concentrations well below this threshold when studied by the same method (2). We also measured the plasma dexamethasone concentrations. All were above the value of $6 \mathrm{nmol} / \mathrm{l}$ proposed as a threshold for adequate suppression in non-depressed subjects at $0800 \mathrm{~h}$, and all but two (with values of 1.5 and $1.7 \mathrm{nmol} / \mathrm{l}$ ) were above the proposed threshold of $2 \mathrm{nmol} / \mathrm{l}$ at $1600 \mathrm{~h} \mathrm{(20).} \mathrm{Moreover,} \mathrm{there} \mathrm{was} \mathrm{no}$ significant correlation between the plasma cortisol and dexamethasone concentrations within the group of patients. We conclude that in hip-fracture patients, as in depressed patients (14) and elderly patients with depression or dementia (21), the impaired suppression of cortisol was not primarily due to abnormally rapid clearance of dexamethasone.

There is evidence that dexamethasone inhibits the hypothalamo-pituitary-adrenal (HPA) axis primarily at the pituitary level $(9,22$; but see 23) and by a mechanism involving changes in transcription, although not necessarily of the gene responsible for adrenocorticotrophin synthesis (24). It is well known that feedback inhibition of the axis can be overridden by noxious stimuli and that this ability is a function of both the nature and strength of the stimulus (24). It is unlikely that the classical stimuli after injury, fluid loss and pain, are still present at 2 weeks in hip-fracture patients who have been treated by fluid replacement and surgery. Thus it is possible that resistance to dexamethasone reflects an impairment in the mechanism of suppression itself, either in the pituitary or at distant sites such as the hippocampus, where such an impairment would lead to an increase in vasopressin and possibly corticotrophin-releasing factor drive (25). There could be a decrease in the abundance of GR, for example by down-regulation (11). Alternatively, the ability of bound GR to affect gene transcription could be impaired. A possible cause is the presence of cytokines, which are another stimulus to the HPA axis (26). Cytokines and glucocorticoids can inhibit each other's effects by direct interactions between their transcription factors as well as at the genomic level (27). We have 
found increased circulating concentrations of tumour necrosis factor receptor and interleukin-1 receptor antagonist 2 weeks after hip fracture (I P M O'Connell, R N Barton \& M A Horan, unpublished observations), suggesting a generally raised level of cytokine activity. Thus in the present experiments it was necessary to measure both GR and a glucocorticoid effect to find out whether there was general resistance to glucocorticoids.

We used PBMLs as a model tissue in which to study the binding parameters of GRs and an effect known to be mediated by GRs (28), namely inhibition of lectin-induced mitogenesis. There was no difference between the patients and control subjects in either total GR-binding capacity or inhibition of $\left[{ }^{3} \mathrm{H}\right]$ thymidine incorporation by a near-saturating dexamethasone concentration (Table 2). However, the findings with regard to binding affinity and sensitivity to inhibition were not so consistent. The injured women had a higher $K_{\mathrm{d}}$, i.e. a lower affinity of binding, than the control subjects (Table 2). However, there was no corresponding change in the $\mathrm{IC}_{50}$ for inhibition of $\left[{ }^{3} \mathrm{H}\right]$ thymidine incorporation; on the contrary, the $\mathrm{IC}_{50}$ at a ConA concentration of $10 \mu \mathrm{g} / \mathrm{ml}$ was lower in the patients than in the control subjects, while there was no difference in $\mathrm{IC}_{50}$ between the groups at $1 \mu \mathrm{g} / \mathrm{ml}$ ConA. Thus this assay tended to show a heightened sensitivity to glucocorticoids rather than a diminished one as the binding assay would predict.

These indices are influenced by a large number of factors. The exact meaning of $K_{\mathrm{d}}$ is not completely clear because the steroid-GR complex exists in several forms owing to activation and translocation to the nucleus (29); once activation has occurred, dissociation takes place via a different route (30). This heterogeneity is revealed by dissociation kinetics even though equilibrium studies show a single class of binding site (31). The sensitivity of $\left[{ }^{3} \mathrm{H}\right]$ thymidine incorporation to glucocorticoids depends on yet more factors since it decreases as the concentration of mitogen is raised from suboptimal to optimal (32), as our results confirm (Fig. $3)$. This additional complexity may account for the much greater variability of $\mathrm{IC}_{50}$ than of $K_{\mathrm{d}}$ (Table 2 ) and possibly also for the tendency of $\mathrm{IC}_{50}$ to be lower than $K_{\mathrm{d}}$, as observed previously (33). Without a greater understanding of the control of these variables, interpretation of the opposite changes in $K_{\mathrm{d}}$ and $\mathrm{IC}_{50}$ is difficult. We can only conclude that there is no consistent impairment of sensitivity to glucocorticoids in elderly hip-fracture patients.

The comparisons in these assays could have been biased by two differences between the patients and control subjects. First, the fewer lymphocytes in the blood of the patients led to a higher monocyte content in the PBML preparation (Table 2). Since monocytes have around twice as many receptors per cell as lymphocytes (34), the difference in composition should have caused the patients to have a $10-20 \%$ higher GR content than the controls. This probably accounted for the nonsignificant 15\% difference observed (Table 2). There should have been no bias in the comparison of $K_{d}$, which is similar in lymphocytes and monocytes (34). Monocytes are known to influence proliferation of lymphocytes through production of cytokines such as interleukin-1 (35), and in theory the mitogenesisinhibition assay could have been affected by the difference in composition of the cell preparations. Addition of monocytes to lymphocytes greatly desensitises them to inhibition of $\left[{ }^{3} \mathrm{H}\right]$ thymidine incorporation by cortisol (36). However, the effect is maximal when the monocyte content reaches 5\%. Our own preliminary data showed no change in the percentage inhibition by various doses of dexamethasone (in the presence of $10 \mu \mathrm{g} / \mathrm{ml}$ ConA) if the monocyte content was reduced from 18 to $3 \%$ or if it was increased in stages from 12 to $42 \%$. Therefore, it seems unlikely that the difference in cellular composition biased the comparison between the two groups.

The second possible source of bias in the mitogenesisinhibition assay lies in the smaller stimulation of $\left[{ }^{3} \mathrm{H}\right]$ thymidine incorporation by Con $\mathrm{A}$, in the absence of dexamethasone, in the cells of the patients than in the control cells (Fig. 2). The implications of this difference in baseline are uncertain. In PBMLs stimulated by another lectin, phytohaemagglutinin, there is a highly significant positive correlation between the $\mathrm{IC}_{50}$ for dexamethasone and $\left[{ }^{3} \mathrm{H}\right]$ thymidine incorporation in its absence (37), raising the possibility that the greater sensitivity in the injured was secondary to their lower proliferative response to ConA. However, we found no such relationship in either the patients or the control subjects. There was a weak correlation between maximal inhibition and baseline $\left[{ }^{3} \mathrm{H}\right]$ thymidine incorporation in the patients at a ConA concentration of $1 \mu \mathrm{g} / \mathrm{ml}$, but not at $10 \mu \mathrm{g} / \mathrm{ml}$, when the range of values was greater and any important relationship should have become apparent. There is therefore no evidence from our data that the difference in stimulation by ConA was an important source of bias.

What are the implications of the current findings for cortisol actions in hip-fracture patients? The mitogenesis-inhibition assay in PBMLs has been used to investigate peripheral sensitivity to glucocorticoids in many different conditions such as depression (12), asthma $(33,38)$, rheumatoid arthritis (13) and kidney transplantation (39). Most workers have found it to be of value in identifying patients resistant to treatment with glucocorticoids $(13,33,39)$. Such patients do not usually show changes in glucocorticoid-binding parameters in their PBMLs $(33,40)$. The very rare patients with glucocorticoid resistance due to mutations in GR show reduced ability of glucocorticoids to inhibit mitogenesis as well as impaired binding in PBMLs (41). On this basis it seems reasonable to expect that hip-fracture patients would show normal sensitivity to any immunosuppressive effects of their raised cortisol concentrations. 
The question of what such effects might be is an important one, given the raised death rate for several months after proximal femur fracture (4). Increased neutrophil and decreased lymphocyte counts are seen for a short time after injury and have been attributed to the effects of cortisol (42). Animal experiments confirm that the acute neutrophilia and lymphopenia caused by stress are largely mediated by endogenous corticosteroids (43). Since similar changes in white cell counts were seen in our patients (Table 2), it is possible that the persistently raised cortisol concentration was responsible. Whether it is likely to have had effects on the function of these cells is uncertain. Although many of the immunosuppressive effects of trauma can be reproduced by glucocorticoids, the dose-response curves, time courses etc. often argue against a causal relationship $(42,43)$. It should be noted that the effects of glucocorticoids on the immune system are extremely complex and not all are inhibitory $(26,43)$. Teleologically such responses may have evolved to prepare the immune system to fight infection (43) or to prevent it from remaining harmfully activated once the infection has been controlled (26). It remains to be seen whether either theory has relevance to hip-fracture patients or whether any immunological effects of their raised cortisol concentrations are merely the result of pathological changes in the hippocampus or elsewhere.

PBMLs are often taken as a paradigm for peripheral tissues in general, and on this basis our results provide evidence against resistance to glucocorticoid effects in non-immunological tissues. However, there is a growing list of possible reasons for variations in glucocorticoid sensitivity between tissues, such as differences in their content of $11 \beta$-hydroxysteroid dehydrogenase (44), mineralocorticoid receptors (45), heat-shock proteins (46), other endogenous regulators of GR function (29) and transcription factors mediating other effects (27). Studies of the association between cortisol concentrations and putative glucocorticoid actions in other tissues are now required.

\section{Acknowledgements}

We are indebted to the consultant orthopaedic surgeons at Hope Hospital and Stockport Infirmary for permission to study their patients, to Professor P Vecsei (University of Heidelberg, Germany) for providing the dexamethasone antiserum, to Dr S K Cunningham (St Vincent's Hospital, Dublin, Ireland) for details of his dexamethasone RIA, to Mrs L Gibbons for help with the mononuclear-leucocyte methods and to $\mathrm{Mr} \mathrm{T}$ Rainey for measuring plasma cortisol.

\section{References}

1 Frayn KN, Stoner HB, Barton RN, Heath DF \& Galasko CSB. Persistence of high plasma glucose, insulin and cortisol concentrations in elderly patients with proximal femoral fractures. Age and Ageing $19831270-76$.
2 Roberts NA, Barton RN, Horan MA \& White A. Adrenal function after upper femoral fracture in elderly people: persistence of stimulation and the roles of adrenocorticotrophic hormone and immobility. Age and Ageing 199019 304-310.

3 Barton RN, Weijers JWM \& Horan MA. Increased rates of cortisol production and urinary free cortisol excretion in elderly women 2 weeks after proximal femur fracture. European Journal of Clinical Investigation 199323 171-176.

4 Horan MA, Barton RN \& Little RA. Ageing and the response to injury. In Advanced Geriatric Medicine, vol 7, pp 101-135. Eds J Grimley Evans \& FI Caird. London: Wright, 1988.

5 Greatorex IF. Proximal femoral fractures: an assessment of the outcome of health care in elderly people. Community Medicine $198810203-210$.

6 Goforth P \& Gudas CJ. Effects of steroids on wound healing: a review of the literature. Journal of Foot Surgery $19801922-$ 28.

7 Sugden PH \& Fuller SJ. Regulation of protein turnover in skeletal and cardiac muscle. Biochemical Journal 1991273 21-37.

8 Doncaster HD, Barton RN, Horan MA \& Roberts NA. Factors influencing cortisol-adrenocorticotrophin relationships in elderly women with upper femur fractures. Journal of Trauma 199334 49-55.

9 de Kloet ER. Brain corticosteroid receptor balance and homeostatic control. Frontiers in Neuroendocrinology 199112 95-164.

10 Mayer M, Shafrir E, Kaiser N, Milholland RJ \& Rosen F. Interaction of glucocorticoid hormones with rat skeletal muscle: catabolic effects and hormone binding. Metabolism 197625 157-167.

11 Burnstein KL \& Cidlowski JA. The down side of glucocorticoid receptor regulation. Molecular and Cellular Endocrinology 199283 $\mathrm{C} 1-\mathrm{C} 8$.

12 Lowy MT, Reder AT, Gormley GJ \& Meltzer HY. Comparison of in vivo and in vitro glucocorticoid sensitivity in depression: relationship to the dexamethasone suppression test. Biological Psychiatry 198824 619-630.

13 Kirkham BW, Corkhill MM, Davison SC \& Panayi GS. Response to glucocorticoid treatment in rheumatoid arthritis: in vitro cell mediated immune assay predicts in vivo responses. Journal of Rheumatology 199118 821-825.

14 Lowy MT \& Meltzer HY. Dexamethasone bioavailability: implications for DST research. Biological Psychiatry 198722 373-385.

15 Miller GA \& Morahan PS. Use of non-specific esterase stain. In Methods for Studying Mononuclear Phagocytes, pp 367-374. Eds DO Adams, PJ Edelson \& H Koren. New York: Academic Press, 1981.

16 Keightley DD \& Cressie NAC. The Woolf plot is more reliable than the Scatchard plot in analysing data from hormone receptor assays. Journal of Steroid Biochemistry 198013 1317-1323.

17 Snedecor GW \& Cochran WG. Statistical Methods, edn 6. Ames: Iowa State University Press, 1967.

18 Kendall MG \& Dickinson Gibbons J. Rank Correlation Methods, edn 5. London: Edward Arnold, 1990.

19 Carroll BJ, Feinberg M, Greden JF, Tarika J, Albala AA, Haskett RF et al. A specific laboratory test for the diagnosis of melancholia. Standardization, validation, and clinical utility. Archives of General Psychiatry 198138 15-22.

20 O'Sullivan BT, Hunt GE, Johnson GF \& Caterson ID. The plasma dexamethasone window: evidence supporting its usefulness to validate dexamethasone suppression test results. Biological Psychiatry 199225 739-754.

21 Ferrier IN, Pascual J, Charlton BG, Wright C, Leake A, Griffiths HW et al. Cortisol, ACTH, and dexamethasone concentrations in a psychogeriatric population. Biological Psychiatry 198823 252-260.

22 Miller AH, Spencer RL, Pulera M, Kang S, McEwen BS \& Stein M. Adrenal steroid receptor activation in rat brain and pituitary following dexamethasone: implications for the dexamethasone suppression test. Biological Psychiatry 199232 850-869.

23 Feldman S \& Weidenfeld J. Neural mechanisms involved in the corticosteroid feedback effects on the hypothalamo-pituitaryadrenocortical axis. Progress in Neurobiology 199545 129-141. 
24 Keller-Wood ME \& Dallman MF. Corticosteroid inhibition of ACTH secretion. Endocrine Reviews 19845 1-24.

25 Jacobson L \& Sapolsky R. The role of the hippocampus in feedback regulation of the hypothalamic-pituitary-adrenal axis. Endocrine Reviews 199112 118-134.

26 Besedovsky HO \& del Rey A. Immune-neuro-endocrine interactions: facts and hypotheses. Endocrine Reviews 199617 64-102.

27 Truss M \& Beato M. Steroid hormone receptors: interaction with deoxyribonucleic acid and transcription factors. Endocrine Reviews $199314459-479$.

28 Wiegers GJ, Croiset G, Reul JMHM, Holsboer F \& de Kloet ER. Differential effects of corticosteroids on rat peripheral blood Tlymphocyte mitogenesis in vivo and in vitro. American Journal of Physiology 1993265 E825-E830.

29 Bodine PV \& Litwack G. The glucocorticoid receptor and its endogenous regulators. Receptor 19901 83-119.

30 Munck A \& Holbrook NJ. Glucocorticoid-receptor complexes in rat thymus cells. Rapid kinetic behavior and a cyclic model. Journal of Biological Chemistry 1984259 820-831.

31 Murakami T, Brandon D, Rodbard D, Loriaux DL \& Lipsett MB. Glucocorticoid receptor in circulating mononuclear leukocytes. Endocrinology 1979104 500-505.

32 Goodwin JS, Messner RP \& Williams RC Jr. Inhibitors of T-cell mitogenesis: effect of mitogen dose. Cellular Immunology 197945 303-308.

33 Corrigan CJ, Brown PH, Barnes NC, Szefler SJ, Tsai J-J, Frew AJ et al. Glucocorticoid resistance in chronic asthma. Glucocorticoid pharmacokinetics, glucocorticoid receptor characteristics, and inhibition of peripheral blood $\mathrm{T}$ cell proliferation by glucocorticoids in vitro. American Review of Respiratory Disease 1991144 1016-1025

34 Lippman M \& Barr R. Glucocorticoid receptors in purified subpopulations of human peripheral blood lymphocytes. Journal of Immunology 1977118 1977-1981.

35 Oppenheim JJ, Stadler BM, Siraganian RP, Mage M \& Mathieson B. Lymphokines: their role in lymphocyte responses. Properties of interleukin 1. Federation Proceedings 198241 257-262.

36 Stites DP, Bugbee S \& Siiteri PK. Differential actions of progesterone and cortisol on lymphocyte and monocyte interaction during lymphocyte activation: relevance to immunosuppression during pregnancy. Journal of Reproductive Immunology 19835 215-228.
37 Pukhalsky AL, Kalashnikova EA, Lyashko VN \& Pevnitsky LA. Inhibition of phytohemagglutinin-induced lymphocyte proliferation by dexamethasone: mechanisms of individual susceptibility. International Journal of Immunopharmacology 1990 12 657-663.

38 Alvarez J, Surs W, Leung DYM, Iklé D, Gelfand EW \& Szefler SJ. Steroid-resistant asthma: immunologic and pharmacologic features. Journal of Allergy and Clinical Immunology $199289714-$ 721.

39 Langhoff E, Ladefoged J, Jakobsen BK, Platz P, Ryder LP, Svejgaard A et al. Recipient lymphocyte sensitivity to methylprednisolone affects cadaver kidney graft survival. Lancet 19861 1296-1297.

40 Sher ER, Leung DYM, Surs W, Kam JC, Zieg G, Kamada AK et al. Steroid-resistant asthma. Cellular mechanisms contributing to inadequate response to glucocorticoid therapy. Journal of Clinical Investigation 199493 33-39.

41 Lamberts SWJ, Koper JW, Biemond P, den Holder FH \& de Jong FH. Cortisol receptor resistance: the variability of its clinical presentation and response to treatment. Journal of Clinical Endocrinology and Metabolism 199274 313-321.

42 Calvano SE. Hormonal mediation of immune dysfunction following thermal and traumatic injury. In Advances in Host Defense Mechanisms: Vol. 6 Host Defenses in Trauma and Surgery, pp 111-142. Eds JM Davis \& GT Shires. New York: Raven, 1986.

43 McEwen BS, Biron CA, Brunson KW, Bulloch K, Chambers WH, Dhabhar FS et al. The role of adrenocorticoids as modulators of immune function in health and disease: neural, endocrine and immune interactions. Brain Research Reviews 199723 79-133.

44 Stewart PM. 11ß-Hydroxysteroid dehydrogenase. Baillière's Clinical Endocrinology and Metabolism 19948 357-378.

45 de Kloet ER, Oitzl MS \& Schöbitz B. Cytokines and the brain corticosteroid receptor balance: relevance to pathophysiology of neuroendocrine-immune communication. Psychoneuroendocrinology $199419121-134$.

46 Vamvakopoulos NO. Tissue-specific expression of heat shock proteins 70 and 90: potential implication for differential sensitivity of tissues to glucocorticoids. Molecular and Cellular Endocrinology 199398 49-54.

Received 4 February 1998

Accepted 23 February 1998 